J. Clin. Chem. Clin. Biochem.

Vol. 14, 1976, pp. 217-223

\title{
Enzymatic Determination of Cholesterol in Serum Lipoproteins ${ }^{1}$ )
}

\author{
By Ingeborg R. Kupke
}

Institute of Clinical Chemistry (Director: Prof. Dr. Dr. J. Büttner), Medizinische Hochschule Hannover, Germany

(Received May 2, 1975/January 8, 1976)

Summary: A new method for the quantitative determination of the cholesterol content of serum lipoproteins is described. Electrophoresis of the serum lipoproteins on agarose gel is followed by the enzymatic determination of the lipoprotein cholesterol. The cholesterol is released from the agarose pieces containing the lipoproteins by dissolving the agarose with $\mathrm{HCl}$. No influence of the $\mathrm{HCl}$ on cholesterol, and no influence of the agarose degradation products on the enzyme reactions was observed. The analytical procedure is simple and only $20 \mu l$ serum are required. The average coefficient of variation for the determination of the $\beta$-lipoprotein cholesterol is $<4 \%$, and it is $<8 \%$ in the pre- $\beta$-lipoproteins of Type IV hyperlipidemic patients. The cholesterol contents found in the other lipoprotein fractions have to be interpreted as an approximation. Semiautomation seems to be possible.

In preliminary studies, the cholesterol concentrations of the serum lipoproteins were determined in some control subjects and in some hyperlipidemic patients. The results are in good agreement with data obtained by ultracentrifuge studies performed by other investigators.

The advantages of this new procedure and aspects of application are discussed.

\section{Enzymatische Bestimmung von Cholesterin in Serum-Lipoproteinen}

Zusammenfassung: Ein neues Verfahren zur quantitativen Bestimmung von Cholesterin in Serum-Lipoproteinen wird beschrieben. Die Lipoproteine werden mittels Elektrophorese auf Agarosegel gewonnen und anschließend wird der Cholesteringehalt enzymatisch bestimmt. - Durch Auflösen der Agarose in $\mathrm{HCl}$ werden die Lipide und damit auch das Cholesterin frei gesetzt. Die $\mathrm{HCl}$ hat keinen meßbaren Einfluß auf das Cholesterinmolekül und die Agaroseabbauprodukte interferieren nicht mit den Enzymreaktionen. Das Verfahren ist einfach und zeichnet sich durch einen geringen Serumbedarf von $20 \mu \mathrm{l}$ aus. Der durchschnittliche Variationskoeffizient beträgt für die Bestimmung des Cholesteringehalts in den $\beta$-Lipoproteinen $<4 \%$ und für die prä-fj-Lipoproteine der Hyperlipidämieform Typ IV $<8 \%$. Die Cholesteringehalte der anderen Fraktionen sind Näherungswerte. Eine Adaptation an die Semiautomation scheint möglich zu sein.

In vorläufigen Untersuchungen wurde der Cholesteringehalt in Serum-Lipoproteinen von einigen Kontrollpersonen und einigen hyperlipidämischen Patienten ermittelt. Die Ergebnisse sind weitgehend mit Werten vergleichbar, welche von anderen Autoren mittels Ultrazentrifugation und añschließender Cholesterinbestimmung erzielt wurden.

Die Vorteile dieses neuen Verfahrens und Anwendungsmöglichkeiten werden diskutiert.

\section{Introduction}

Epidemiologic, clinical, and biochemical studies indicate that an elevated cholesterol content in the human blood serum and, therefore, in the serum lipoproteins, is one

\footnotetext{
1) Presented at the meeting of the German, Austrian and Swiss Societies of Clinical Chemistry, March, 16-18, 1975, Freiburg i. Br., Germany, and at the Ninth International Congress on Clinical Chemistry, July,13-18, 1975, Toronto, Canada.
}

of the cumulative risk factors involved in the process of atherogenesis and coronary heart disease. The determination of this cholesterol is widely used as a tool for prognosis, diagnosis, and therapy control.

The serum lipoproteins are usually prepared by ultracentrifugation followed by the determination of cholesterol (1-12). This method, although accepted to be the reference method, is time consuming, and relatively large amounts of serum are required. Furthermore, the 
availability of an ultracentrifuge is still restricted to specialized laboratories and research centers. For largescale studies, more simple and rapid procedures were developed for the fractionation of the serum lipoproteins, such as precipitation $(4,13-19)$, or as a formula for the approximation of the cholesterol content in the lipoproteins, especially in the $\beta$-lipoproteins $(5,10,20)$.

The separation of the serum lipoproteins by electrophoresis on agarose gel is more simple and smaller amounts of serum are needed. These lipoprotein fractions may be analyzed in different ways. After lyophilization the lipids can be extracted by organic solvents (21). Ashing the material can be followed by the determination of phospholipid phosphorus (22). Radioactive samples such as $\left[{ }^{3} \mathrm{H}\right]$ cholesterol-labelled lipoproteins can be measured by liquid scintillation spectrophotometry $(23,24)$.

It was the purpose of the present study to combine electrophoresis of the serum lipoproteins on agarose gel $(25,26)$ with the enzymatic determination of cholesterol (27). The structure of the agarose gel is destroyed by $\mathrm{HCl}$, and, among the other lipids, cholesterol and cholesterolesters are released. After the neutralization of the samples, the enzymatic determination of cholesterol can be carried out.

\section{Equipment}

CORNING-EEL/IMA-micro-electrophoresis system (D-6300 Gießen) and BOSCAMP-microphor system (D-5503 Hersel).

\section{Chemicals}

SERVA, D-6900 Heidelberg: Barbital-sodium phosphate buffer, $0.05 \mathrm{~mol} / 1, \mathrm{pH} 8.2$ (No. 38 185), $8 \mathrm{~g} / \mathrm{l}$ agarose gel (INSTANTGEL, No. A-08-82), human albumin stained with bromphenol blue and vitamin B12 (No. 11 885).

BEHRING, D-3550 Marburg: Bovine albumin.

MERCK, D-6701 Darmstadt: Ethanol, methanol, conc. hydrochloric acid, acetic acid, $\left(\mathrm{NH}_{4}\right) \mathrm{H}_{2} \mathrm{PO}_{4}$, and $\left(\mathrm{NH}_{4}\right)_{2} \mathrm{HPO}_{4}$ (all chemicals p.a.); sodium hydroxide, purissimum, Sudan black.

BOEHRINGER, D-6800 Mannheim: Catalase $(1 \mathrm{~g} / 50 \mathrm{ml}$ ) (No. 15 674), and Biochemica Test Combination Cholesterol (No. 15 738). The composition of the commercial solutions of this Test Combination is as follows:

Solution 1: $0.6 \mathrm{~mol} / \mathrm{l}$ ammonium phosphate buffer, $\mathrm{pH} 7$, $1.7 \mathrm{~mol} / \mathrm{l}$ methanol; $>700 \mathrm{kU} / \mathrm{l}$ catalase.

Solution 2: $0.42 \mathrm{~mol} / 1$ acetylacetonc; $2.5 \mathrm{~mol} / 1$ methanol; $21 \mathrm{~g} / 1$ hydroxypolyethoxydodecane.

Solution 3: $>7 \mathrm{kU} / \mathrm{l}$ cholesterol esterase.

Solution 4: $>4 \mathrm{kU} / \mathrm{l}$ cholesterol oxidase.

Solution 5: For the determination of the total serum cholesterol (27), a reaction mixture is prepared from 10 parts of solution $1,0.50$ parts of solution 2, and 0.04 parts of solution 3.

Solution V: For the determination of the serum lipoprotein cholesterol, a modified reaction mixture is prepared from 10 parts of solution $1,0.75$ parts of solution 2, 0.06 parts of solution $3, \dot{0} .4$ parts of methanol, and 0.004 parts of the catalase preparation.

\section{Phenoty ping of the lipoprotein pattern}

For this purpose, the serum lipoproteins are separated by the CORNING-EEL/IMA-micro-electrophoresis system. Only one $\mu l$ serum is needed, and the whole procedure is finished within one hour. The lipids are stained with Oil red 0.

The different patterns of hyperlipidemia were classified according to Fredrickson et al. (28), and according to the recommendations of an experit committee of the World Health Organization (29).

\section{Separation of the lipoproteins}

Lipoprotein electrophoresis on agarose gel using fresh human serum is performed as described by Kahlke $(25,26)$, and as recommended by the BOSCAMP-Comp. The following modifications are introduced:

1. $3.5 \mathrm{ml} 8 \mathrm{~g} / \mathrm{l}$ agarose gel are applied to one microscope slide;

2. two parts of serum and one part of $16 \mathrm{~g} / \mathrm{l}$ agarose gel, warmed to $56^{\circ} \mathrm{C}$, are mixed, and a very small amount of the stained human albumin powder is added. $30 \mu$ of this mixture are applied with a micro-pipette to the groove of one agarose block;

3. electrophoresis is carried out at $6 \mathrm{~mA}$ per sample during 90 minutes;

4. for fixation, the samples are exposed to $20 \mathrm{~g} / \mathrm{l}$ acetic acid for 10 minutes only; thereafter, they are washed with distilled water for 5 minutes;

5. the pherograms are covered with wet filter paper and moisture is evaporated under a warm air stream as long as the agarose layer can be lifted from the slide, and the filter paper remains slightly wet. This takes approximately 20-30 minutes.

\section{Localization of the lipoproteins}

After fixation, the lipoproteins become visible by opalescence. In addition, the albumin band prestained with bromphenol blue can serve for further orientation. Parallel pherograms can be stained in the common way with Sudan black or with other lipid stains, and the unstained fractions can be cut according to the stained pattern.

Enzy matic determination of cholesterol in the presence of agarose

Step 1

Agarose samples containing known amounts of serum cholesterol are transferred to centrifuge tubes. The agarose pieces containing the lipoprotein fractions are rolled around a small glas rod and they are also transferred together with this glass rod to centrifuge tubes. In this stage the samples can be stored at $+4^{\circ} \mathrm{C}$ for several days, if neccessary.

Step 2

$0.3 \mathrm{ml}$ conc. $\mathrm{HCl}$ are added. The agarose is dissolved within a few seconds by swirling the sample vigorously on a vibrator. Immediately afterwards, the centrifuge tubes are transferred to a cooling bath, prepared from ice water and sodium chloride.

Step 3 .

$0.2 \mathrm{ml}$ of the saturated ammonium phosphate buffer, $\mathrm{pH} 7$, are added. Do not shake the samples!

Step 4

$0.4 \mathrm{ml}$ of the sodium hydroxide solution $(300 \mathrm{~g} / \mathrm{l})$ are added.

Step 5

After 5 minutes, the samples are mixed carefully. 
Step 6

$3.0 \mathrm{ml}$ of solution $\mathrm{V}$ are added. Each tube is taken out immediately from the cooling bath. The samples are mixed again and incubated at $37^{\circ} \mathrm{C}$ for 30 minutes. Afterwards, they are centrifuged at $3000 \mathrm{rpm}$ for 15 minutes. One $\mathrm{ml}$ of this preincubated mixture is used for the oxidase reaction:

\section{Step 7}

$\begin{array}{ll}\text { sample blank } & \text { sample } \\ 1 \mathrm{ml} & 1 \mathrm{ml} \\ - & 0.01 \mathrm{ml}\end{array}$

Preincubated mixture

Solution 4 (cholesterol oxidase)

$0.01 \mathrm{ml}$

The samples are mixed and incubated at $37^{\circ} \mathrm{C}$ for at least 60 minutes. They are cooled down to room temperature and measured at $405 \mathrm{~nm}$ in semi-micro glass cuvettes (pathlength $1 \mathrm{~cm}$ ), each sample against its own sample blank.

Determination of the serum triacylglycerols

The triacylglycerols (triglycerides) are determined enzymatically by the BOEHRINGER, Mannheim "Test Combination Neutral Fat (Triglycerides) and Glycerol".

\section{Calculations}

The percent distribution of the total serum cholesterol between the lipoproteins is calculated: $\Delta \mathbf{A}(\alpha-+$ pre- $\beta-+\beta$-lipoproteins) $=100 \%$. The cholesterol concentration of each lipoprotein fraction can be calculated by referring the corresponding percentage to the total cholesterol content of the serum.

The data are expressed as $\bar{x} \pm s_{x}(C V, \%)$, where $\bar{x}=$ mean value, $s_{\mathbf{x}}=$ standard deviation, $\mathrm{CV}=$ coefficient of variation $=$ precision in the series, $n=$ number of experiments.

\section{Results and Discussion}

\section{Principle}

Cholesterol distributed in agarose gel can be determined enzymatically with the modification according to Roeschlau et al. (27). The agarose samples containing the cholesterol are dissolved in conc. $\mathrm{HCl}$. During this procedure, the gel structure of the agarose is destroyed, and, as in the hydrolysis of other polysaccharides or peptides by $\mathrm{HCl}$, partial hydrolysis of the galacto-polysaccharide to agarobiose and galactose may occur, thereby releasing the cholesterol. After neutralization, the enżymatic determination of cholesterol can be performed. This procedure is suitable for the determination of the cholesterol moiety of serum lipoprotein fractions separated by electrophoresis on agarose gel modified according to Kahlke $(25,26)$.

\section{Dissolution of the agarose}

After the dissolution of the agarose by $\mathrm{HCl}$, the samples are cooled carefully. This step appears to be an important factor in this procedure. Saturated ammonium phosphate buffer is added in order to increase the buffer capacity of the final system, and in order to dilute the conc. $\mathrm{HCl}$ before neutralization with the $\mathrm{NaOH}$ solu- tion. It is advisible to allow the samples to equilibrate with the surrounding temperature after the addition of each solution. This last step prevents the formation of brownish coloured degradation products of the agarose which do not interfere with the enzyme reaction but which do elevate the optical density of the sample blanks.

\section{Modification of the enzymatic determination of cholesterol}

Solution $\mathrm{V}$ is prepared by modifying the original solution 5 of the "Test Combination Cholesterol" (27) as follows: Except for the buffer, the concentrations of the respective constituents are elevated by the factor 1.5. This should compensate roughly for the dilution caused by the large volume of the neutralized sample, thereby approximating the optimal conditions for the enzyme reactions.

After the addition of solution $\mathrm{V}$ to the neutralized samples, the tubes are taken out from the cooling bath immediately in order to avoid the precipitation of salts present at high concentrations.

During the preincubation period prior to the addition of the cholesterol oxidase, the agarose degradation products are precipitated - probably by the organic solvents present in the sample - and can be eliminated by centrifugation. This can also be done after the incubation with the cholesterol oxidase; however, in this case, the number of tubes to be centrifuged would be doubled because each sample has its own blank.

Comparison of the modified method with the original method

As compared to the original serum method (27), the efficiency of the enzyme reaction in this modified method is $97 \%$ (tab. 1). Accordingly, no relevant influence of the $\mathrm{HCl}$ on cholesterol as a substrate for the cholesterol oxidase exists and there is no interference of the agarose degradation products with the enzyme reactions. These results are consistent with data obtained by studies on the influence of $\mathrm{HCl}$ on the chromatographic properties of cholesterol (in preparation).

The linearity of the calibration curve for the modified method is the same as in the original method. The detection limit is found to be around $0.5 \mathrm{mmol} / \mathrm{l} \mathrm{serum}$, that is an average absorbance of 0.020 per sample. It is planned to lower this detection limit by further modifications.

These results confirm that cholesterol present in agarose gel can be determined enzymatically and quantitatively. 
Tab. 1. Comparison of the modified method with the original method for the determination of cholesterol (27).

In the modified method, agarose samples containing 5 , 10 and $20 \mu \mathrm{l}$ serum are dissolved in the $\mathrm{HCl}$. The volume of the agarose pieces was estimated at about $100 \mu \mathrm{l}$. The procedure is described in the text. Number in paranthesis: coefficient of variation; number of experiments $=10$.

\begin{tabular}{lll}
\hline & modified method & original method \\
\hline $\begin{array}{l}\text { final volume of the } 4.02 \mathrm{ml} \\
\text { incubation mixture }\end{array}$ & $5.02 \mathrm{ml}$ \\
(4.02:5.02 $=0.8)$ & \\
absorbance of samples & \\
$5 \mu \mathrm{l}$ serum & $0.044 \pm 0.002(4.5)$ & $0.037 \pm 0.001(2.7)$ \\
$10 \mu \mathrm{l}$ serum & $0.090 \pm 0.002(2.2)$ & $0.074 \pm 0.001(1.4)$ \\
$20 \mu \mathrm{l}$ serum & $0.181 \pm 0,003(1.6)$ & $0.149 \pm 0.002(1.3)$ \\
$\times 0.8$ & & \\
$5 \mu \mathrm{l}$ serum & $0.035=95 \%$ & \\
$10 \mu \mathrm{l}$ serum & $0.072=97 \%$ & \\
$20 \mu \mathrm{l}$ serum & $0.145=97 \%$ & \\
\hline
\end{tabular}

Determination of the lipoprotein cholesterol

The electrophoretic procedure described above results in a sharp separation of the lipoproteins of $20 \mu l$ serum. There is no overload of the agarose block. By the addition of the stained albumin as a powder, further dilution of the serum is avoided.

Under standardized experimental conditions, involving fixation for exactly 10 minutes and drying as long as the agarose layer can be lifted from the microscope slide, approximately $5 \%$ of the total cholesterol remain in the fixation bath and $15 \%$ in the filter paper used to cover the agarose blocks before drying. These results are consistent with data obtained by radiochemical studies with $\left[{ }^{3} \mathrm{H}\right]$ cholesterol-labelled lipoproteins (in preparation). In addition, 10 minutes for fixation are sufficient to produce the visible opalescence of the lipopro- teins. This opalescence, the albumin band prestained with bromphenol blue, and a parallel pherogram performed by lipid staining with Sudan black or another lipid stain, make it possible to cut the fractions in a reproducible manner. Usually, the $\beta$-band is intensely opaque; the pre- $\beta$-band is more intense if the triacylglycerols are elevated; the upper limit of the $\alpha$-band is marked by the prestained albumin. It is advisable to cut the fractions before drying the agarose blocks.

The agarose pieces can be transferred easily to the centrifuge tubes by rolling them around a small glass rod. In addition, the vibrations of the glass rod caused by the vibrator enhance the dissolution of the agarose with $\mathrm{HCl}$. After neutralization, the cholesterol is measured by the modified enzymatic procedure.

\section{Precision}

The precision in the series was determined in four control sera, five Type IIlb and in two Type IV hyperlipidemic sera. The coefficients of variation (tab. 2) include the error of the electrophoresis procedure (31); in addition, they are closely related to the cholesterol contents in the corresponding lipoprotein fractions. Therefore, the highest precision of $<4 \%$ is found in the $\beta$ lipoproteins of the controls and of the Type IIb sera. This is followed by the precision obtained for the $\beta$ and pre- $\beta$-lipoproteins of the Type IV sera $(<8 \%)$, by the $\alpha$-lipoproteins in the control sera $(<12 \%)$, and by the other lipoprotein fractions (16-36\%). Accordingly, the exact determination of cholesterol with the modified lipoprotein method can be achieved in the $\beta$-lipoproteins of the controls; and of all the hyperlipidemic sera, and in the pre- $\beta$-lipoproteins of the Type IV sera. The other data have to be interpreted as an approximation because of being measured near the detection limit.

Tab. 2. Precision in the series

The percent distribution of cholesterol in different serum lipoprotein fractions was determined and the precision in the series (CV, \%) was calculated. In the controls and in the Type II bera, the average coefficients of variation were also calculated.

\begin{tabular}{|c|c|c|c|c|c|c|c|c|}
\hline \multirow{3}{*}{$\begin{array}{l}\text { Lipoprotein } \\
\text { pattern }\end{array}$} & \multirow{3}{*}{$\begin{array}{l}\text { cholesterol } \\
\text { (mmol/1 serum) }\end{array}$} & \multirow{3}{*}{$\begin{array}{l}\mathbf{n} \\
7 \\
\mathbf{3} \\
3 \\
7\end{array}$} & \multicolumn{4}{|c|}{ Percent distribution of cholesterol } & \multirow{2}{*}{\multicolumn{2}{|c|}{ a-lipoproteins }} \\
\hline & & & \multicolumn{2}{|c|}{$\beta$-lipoproteins } & \multicolumn{2}{|c|}{ pre- $\beta$-lipoproteins } & & \\
\hline & & & $\begin{array}{l}69.0 \pm 2.2 \\
73.9 \pm 2.2 \\
56.9 \pm 2.9 \\
68.0 \pm 2.3\end{array}$ & $\begin{array}{l}(3.1) \\
(2.9) \\
(5.0) \\
(3.3)\end{array}$ & $\begin{array}{r}6.8 \pm 1.4 \\
4.4 \pm 1.0 \\
17.5 \pm 1.7 \\
13.5 \pm 1.8\end{array}$ & $\begin{array}{l}(21) \\
(23) \\
(10) \\
(13)\end{array}$ & $\begin{array}{l}24.2 \pm 2.0 \\
22.0 \pm 4.4 \\
25.8 \pm 1.5 \\
18.6 \pm 2.5\end{array}$ & $\begin{array}{l}(8) \\
(20) \\
(6) \\
(13)\end{array}$ \\
\hline $\bar{x} \pm s_{x}$ & & & & $(3.6 \pm 1.0)$ & & $(17 \pm 6)$ & & $(12 \pm 6)$ \\
\hline $\begin{array}{l}\text { Type II } b_{1} \\
\text { Type II } b_{1} \\
\text { Type II } b_{2} \\
\text { Type II } b_{3} \\
\text { Type II } b_{4} \\
\text { Type II } b_{5}\end{array}$ & $\begin{array}{l}7.4 \\
7.4 \\
9.5 \\
9.8 \\
7.3 \\
7.8\end{array}$ & $\begin{array}{l}5 \\
7 \\
7 \\
6 \\
6 \\
6\end{array}$ & $\begin{array}{l}79.5 \pm 3.3 \\
76.8 \pm 2.6 \\
79.8 \pm 2.8 \\
77.2 \pm 2.7 \\
75.3 \pm 3.1 \\
73.2 \pm 3.6\end{array}$ & $\begin{array}{l}(4.1) \\
(3.3) \\
(3.5) \\
(3.4) \\
(4.1) \\
(4.9)\end{array}$ & $\begin{array}{l}17.2 \pm 3.1 \\
17.2 \pm 2.4 \\
11.6 \pm 2.2 \\
10.0 \pm 1.9 \\
14.2 \pm 1.3 \\
11.6 \pm 2.3\end{array}$ & $\begin{array}{l}(18) \\
(14) \\
(19) \\
(19) \\
(9) \\
(20)\end{array}$ & $\begin{array}{r}3.2 \pm 0.7 \\
6.1 \pm 2.1 \\
8.9 \pm 2.8 \\
13.5 \pm 2.8 \\
10.5 \pm 2.2 \\
15.0 \pm 2.4\end{array}$ & $\begin{array}{l}(22) \\
(34) \\
(31) \\
(21) \\
(21) \\
(16)\end{array}$ \\
\hline $\bar{x} \pm s_{x}$ & & & & $(3.9 \pm 0.6)$ & & $(16 \pm 4)$ & & $(24 \pm 7)$ \\
\hline $\begin{array}{l}\text { Type IV } \\
\text { Type IV }\end{array}$ & $\begin{array}{l}6.3 \\
5.9\end{array}$ & $\begin{array}{l}7 \\
7\end{array}$ & $\begin{array}{l}52.4 \pm 4.1 \\
45.0 \pm 3.1\end{array}$ & $\begin{array}{l}(7.8) \\
(6.8)\end{array}$ & $\begin{array}{l}35.9 \pm 2.6 \\
45.6 \pm 2.2\end{array}$ & $\begin{array}{l}(7.2) \\
(4.8)\end{array}$ & $\begin{array}{r}11.7 \pm 4.1 \\
9.3 \pm 3.4\end{array}$ & $\begin{array}{l}(35) \\
(36)\end{array}$ \\
\hline
\end{tabular}


LIPOPROTEIN PATTERN

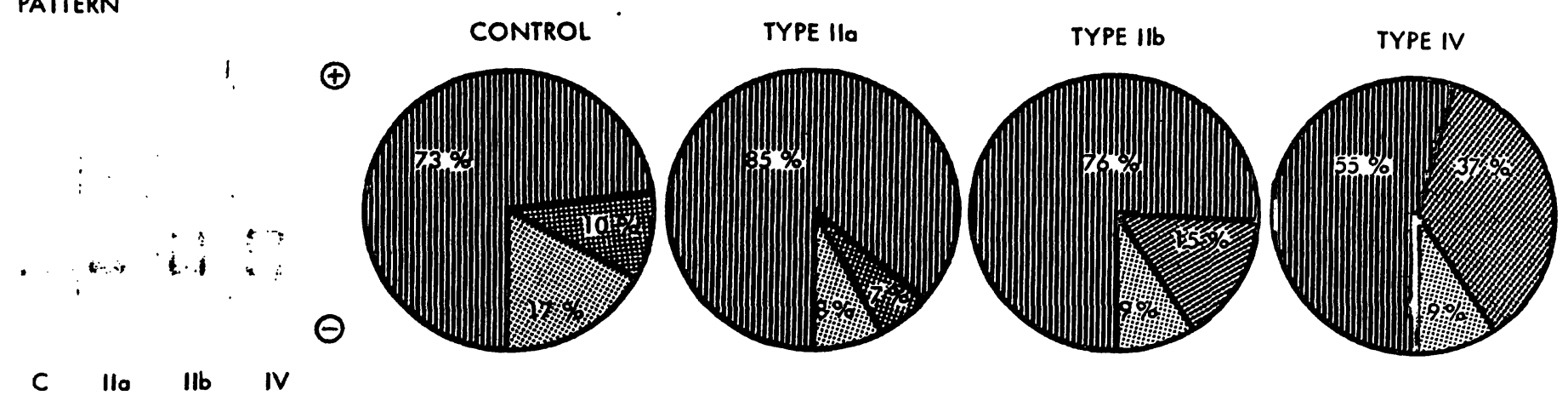

\section{CHOLESTEROL \\ ( $\mathrm{mmol} / \mathrm{l}$ )}

TOTAL SERUM

B-LIPOPROTEINS

PRE- $\beta$-LIPOPROTEINS

$\alpha$-LIPOPROTEINS

TRIACYLGLYCEROLS $(\mathrm{mmol} / \mathrm{I})$

n

$4.7 \pm 0.9$
$3.4 \pm 0.8$
$0.5 \pm 0.2$
$0.8 \pm 0.4$
$1.03 \pm 0.41$
10

10

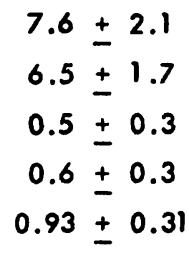

3

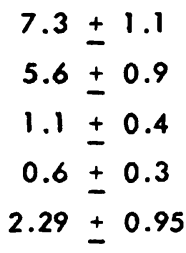

10

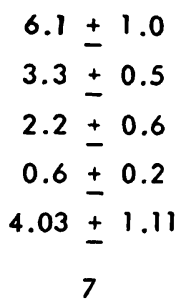

$6.1 \pm 1.0$

$3.3 \pm 0.5$

$2.2+0.6$

$0.6 \pm 0.2$

7

Fig. 1. Percent distribution of cholesterol and cholesterol concentrations in serum lipoproteins.

$C=$ controls, $L P=$ lipoproteins;

WIII = $\beta$-lipoproteins, $\quad$ : :

\section{Cholesterol content of serum lipoproteins}

In preliminary studies, the distribution of cholesterol between the lipoproteins was determined in sera representing different lipoprotein patterns (fig. 1). Prior to agarose electrophoresis for the separation of the lipoprotein fractions, the phenotypes of hyperlipidemia were evaluated with the CORNING-EEL/IMA-microelectrophoresis system. The results obtained with this system are comparable to those obtained with the BOSCAMP-microphor system (fig. 2). The CORNINGEEL system is highly suitable for large-scale studies on the electrophoretic lipoprotein pattern in a given population, e. g. in blood donors (30).

Figure 1 demonstrates that the percentage of the $\beta$ lipoprotein-cholesterol is about the same in the controls and in the Type IIb sera (73 and $76 \%$ ), it is slightly higher in the Type II a sera (85\%), and it is the lowest in the Type IV sera (55\%). In the $\alpha$-lipoproteins, the highest percentage was found in the controls (17\%). In the pre- $\beta$-lipoproteins, the highest percentage was measured in the Type IV sera (37\%). These results are in good agreement with data reported by other authors who have used the ultracentrifuge or precipitation methods for lipoprotein fractionation (tâb. 3). As far as the $\alpha$-lipoproteins of controls are concerned (fig. 1), $\oplus$

$\alpha$-LIPOPROTEINS

PRE- $\beta$-LIPOPROTEINS

-LIPOPROTEINS

ORIGIN
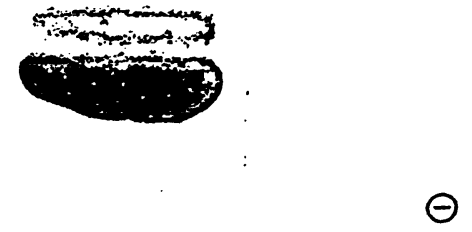

A

B

Fig. 2. Lipoprotein pattern developed with the BOSCAMPmicrophor system (A) and with the CORNING-EEL/ IMA-micro-electrophoresis system (B).

the cholesterol concentrations are much lower, as in the high density lipoproteins (HDL) (tab. 3). This difference may be explained by the observation that the electro- 
Tab. 3. Synopsis of data reported by other investigators.

The cholesterol content was determined in density classes prepared by the ultracentrifuge. The data are expressed in mmol/1. LDL = low density lipoproteins, VLDL = very low density lipoproteins, $\mathrm{HDL}=$ high density lipoproteins. In those cases where the total amount of the lipoproteins was noted, the values found by Ditschuneit (6) served for further calculations. $\mathrm{a}=$ The LDL were prepared by precipitation.

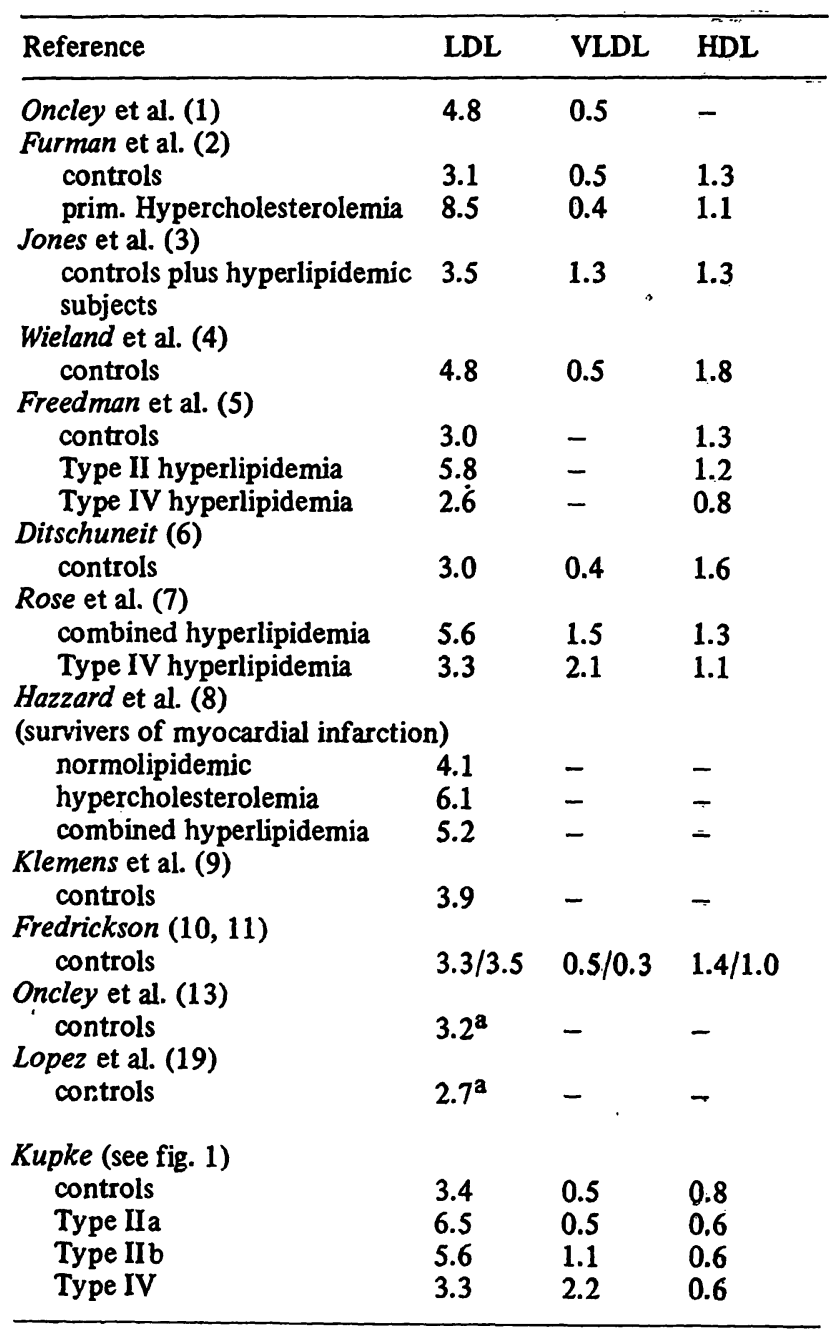

phoretically separated albumin fraction carries roughly the same amount of $\left[{ }^{3} \mathrm{H}\right]$ cholesterol, as compared to the $\alpha$-lipoproteins, if serum is incubated with $\left[{ }^{3} \mathrm{H}\right]$ cholesterol prior to use (in preparation). Presumably, this albumin fraction contains $\alpha$-lipoprotein cholesterol which is not included in the data presented in Figure 1.

With the procedure described in this report, the quantitative determination of cholesterol in electröphoretically separated serum lipoproteins is possible. Parallel studies on the distribution of cholesterol in serum lipoprotein fractions separated by ultracentrifugation and by electrophoresis on agarose gel are planned. Summarizing, the following advantages of this new procedure should be pointed out:

1. A very small amount of serum is required; this makes the procedure suitable for pediatric problems and for experiments with small animals.

2. The performance is simple, and the equipment required should be available in most of the laboratories.

3. Semiautomation and, therefore, large-scale sreening seem to be possible.

4. Presumably, additional criteria for the differentiation between Type IIb and Type IV hyperlipidemia may be elaborated.

\section{Acknowledgement}

The expert technical assistance of Mrs. Chr. Chucholl is gratefully acknowledged. I also wish to thank Mrs. $\dot{G}$. Runge for her help at the beginning of the studies; to Prof. H. Canzler, Division of Nutrition, Medizinische Hochschule Hannover, for the supply of pathological sera; to Dr. H. Haindl, Institute of Nuclear Medicine, Medizinische Hochschule Hannover, for measuring the radioactive samples; and to Boehringer/Mannheim for the generous supply of chemicals.

\section{References}

1. Oncley, J. L. (1963), in "Brain Lipids and Lipoproteins and Leukodystrophies", p. 1-17 (Folchi-Pi, J. \& Brown, H. eds.) Elsevier, Amsterdam.

2. Furman, R. H., Alaupoivic, P. \& Gustafson, A. (1966), in "Pathological and Clinical Aspects of Lipid Metabolism", p. 5-10 (Schettler, G. \& Sanwald, R., eds.) Thieme-Verlag Stuttgart.

3. Jones, R. J., Cohen, L. \& Dobrilovic, L. (1968), J. Atheroscler. 8, 463-470.

4. Wieland, H. \& Seidel, D. (1972), this Journal 10, 311-321.
5. Freedman, F., Buckley, G., Little, J. A. \& Sebriakova, M. (1972), Clin. Biochem. $5,83=87$.

6. Ditschuneit, H. (1973), in "Die Lipoproteine des Blutes" p. 31-41 (Ditschuneit, H., ed.), D. Steinkopf-Verlag.

7. Rose, H. G., Kranz, P., Weinstock, M., Julianò, J. \& Haft, J. I. (1974), Atherosclerosis $20,51-64$.

8. Hazzard, W. R., Goldstein, J. L., Schrott, H. G.; Motulsky, A. G. \& Bierman, E. L. (1974), in "Atherosclerosis IIII", p. 464-468, Proceedings of the Third International Symposium (Schettler, G. \& Wèizel, A., eds.) Springer-Verlag. 
9. Klemens, U. H., Knöchel, W. \& von Löwis of Menar, P. (1974) in "Serumproteine", p. 125-132 (Englhardt, A. \& Lommel, H., eds.) Verlag Chemie, Weinheim/Bergstr.

10. Fredrickson, D. S. \& Levy, R. I. (1972), in "The Metabolic Basis of Inherited Diseases", p. 545-614 (Stanbury, J. B., Wyngaarden, J. B. \& Fredrickson, D. S., eds.) McGrawHill Book Comp.

11. Fredrickson, D. S. (1974) in "Lipid Metabolism, Obesity, and Diabetes Mellitus: Impact upon Atherosclerosis", p. 2-6, Intern. Symposium April 1972 (Greten; H., Levine, R., Pfeiffer, E. F. \& Renold, A. E., eds.), G. Thieme Publ. Stuttgart.

12. Assmann, G. \& Fredrickson, D. S. (1974), in "Atherosclerosis III", p. 641-651, Proceedings of the Third Intern. Symposium (Schettler, G. \& Weizel, A., eds.) SpringerVerlag.

13. Oncley, J. L., Walton, K. W. \& Cornwell, D. G. (1957), J. Amer. Chem. Soc. 79, 4666-4671.

14. Burstein, Par M. \& Samaille, J. (1959), Ann. Biol. Clin., Année XVII, 23-33.

15. Amenta, J. S. \& Waters, L. L. (1960), Yale J. Biol. Med. 33, 112-119.

16. Stokes, R. P., Jacobsson, A. \& Walton, K. W. (1967), J. Atherosclerosis Res. 7, 187-196.

17. Berenson, G. S., Srinivasan, S. R., Pargaonkar, P. S., Radhakrishnamurthy, B. \& Dalferes, E. R. (1972), Clin. Chem. 18, 1463-1467.

18. Searcy, R., Colaianni, W., Young, E., Drnec, J. \& Magoc, T. (1972), Clin. Chim. Acta 38, 291-300.
19. Lopez-s, A., Vial, R., Balart, L. \& Arroyave, G. (1974), Atherosclerosis 20,1-9.

20. Fredrickson, D. S. (1972), Modern Concepts of Cardiovascular Disease XLI, 31-36.

21. Phillips, G. B. \& Wille, L. E. (1973), Clin. Chim. Acta 49, 153-160.

22. Magnani, H. N. \& Alaupovic, P. (1972), Clin. Chim. Acta 38, 405-411.

23. Kupke, I. R. (1972), J. Molecul. Cellul. Cardiol. 4, 255 $-268$.

24. Ritland, St. (1974), Clin. Chim. Acta 55, 359-366.

25. Kahlke, W. (1972), KHA, Heft 8, 470-480.

26. Kahlke, W. (1974), in "Serumproteine", p. 105-110 (Englhardt, A. \& Lommel, H., eds.) Verlag Chemie, Weinheim, Bergstr.

27. Roeschlau, P., Bernt, E. \& Gruber, W. (1974), this Journal 12, 403-407.

28. Fredrickson, D. S., Levy, R. I. \& Lees, R. S. (1967), New England J. Med. 276, 34-44, 94-103, 148-156, 215-224, 273-281.

29. Beaumont, J. L., Carlson, L. A., Cooper, G. R., Fejfar, Z., Fredrickson, D. S. \& Strasser, T. (1970), Bull. Wld Hith Org. 43, 891-915.

30. Kupke, 1. R., Stangl, W. \& Papastvrou, St., 14 th Congress of the Intern. Society of Blood Transfusion, July 27-August 1 , Helsinki 1975.

31. Houtsmuller, A. J. (1969), "Agarose-Gel Electrophoresis of Lipoproteins", van Gorcum and Comp., Prakke, N. V. Dr. H. J. \& Prakke, H.M.G., Assen.

Priv.-Doz. Dr. Ingeborg Kupke Medizinische Einrichtungen der Universität Düsseldorf

Kinderklinik

Moorenstraße 5

D-4000 Düsseldorf 
